\title{
THE BÍLINA TUNNEL - SELECTED GEOTECHNICAL ASPECTS OF A PROPOSED UNDERGROUND STRUCTURE
}

\author{
Viktor SotorníK ${ }^{a, *}$, Petr Černoch ${ }^{b}$, JiŘí KoŠŤÁL ${ }^{c}$ \\ a INSET s.r.o., Divize energetika, Lucemburská 1170/7, 13000 Praha 3 - Vinohrady, Czech Republic \\ ${ }^{b}$ ČEZ Energetické produkty, s.r.o., Komenského 534, 25301 Hostivice, Czech Republic \\ ${ }^{c}$ Czech Technical University in Prague, Faculty of Civil Engineering, Depatment of Geotechnics, Thákurova \\ 2077/7, 16629 Prague, Czech Republic \\ * corresponding author: sotornik.viktor@inset.com
}

\begin{abstract}
Every workday the city of Bílina, with the I/13 road running through it, suffers from traffic congestion. The road is designed as dual carriageway outside Bílina but only as a single carriageway inside the city. Three roundabouts further complicate the situation. As a solution a $1,3 \mathrm{~km}$ long tunnel going under the city was proposed. The preliminary geotechnical investigation describes the geological conditions of the area, suggests the most appropriate localisation details of the tunnel, points out several complications that can be expected and finally offers solutions to mitigate them.
\end{abstract}

KEYWORDS: Aquifer test, CISS, geotechnical investigation, pressure meter test, tunnel.

\section{INTRODUCTION}

Most and Teplice, two major cities in North Bohemia are connected by the I/13 road, and on it halfway between them the city of Bílina is located. The I/13 road is designed as a dual carriageway with only one exception - the Bílina section. The city forms a metaphorical bottleneck that causes regular traffic congestions with queues of cars and trucks several meters long. This situation is further intensified by the existence of three roundabouts located close to each other and by a large number of passing trucks connected to industrial sectors of the city. Since 1980's a solution to mitigate this problem has been researched; several variants of city bypasses [1, a through road in the form of a long overpass or a combination of tunnels and overpasses [2] have all been proposed. However, in the first half of 2018 a so-called Variant Z that includes three alternatives of horizontal alignment in the form of a 1,3 km long tunnel was made public; the tunnel underpasses the bus station, the commercial area and the Mostecké Předměstí district.

Multiple geological units have appeared in the surroundings of Bílina. The bedrock comprises several types of the orthogneiss, belonging to the Ore Mountains massif. Units of Tertiary age are present in the form of igneous rocks, genetically belonging to the Central Bohemian Highlands. The investigation documented both thick basalt layers and layers of pyroclasts. Quaternary sediments can reach a thickness up to $15 \mathrm{~m}$. The naturally occurring fluvial deposits of the Bílina river (of both a sandy and clayey type) are mostly covered with anthropogenic deposits that originated during earthworks that were linked to the coal mining industry located in the city and its surroundings.

\section{Purpose and Goal of the INVESTIGATION}

The main goal of the investigation was to complete the knowledge of the geological conditions in the alignment of the proposed tunnel. According to desk study no boreholes deeper than $15 \mathrm{~m}$ were created; the majority of these boreholes did not even reach the bedrock. A basic hydro-geological evaluation was also made. Results of laboratory tests of soils and rocks were used, beside other things, for evaluation of the sustainability of excavated materials for embankment construction. Based on these results, the most suitable alternative of the tunnel alignment was suggested, including classification of the NATM excavation support classes. At the same time complications that are to be expected during following stages of both the investigation and design work were identified including suggestions to mitigate them.

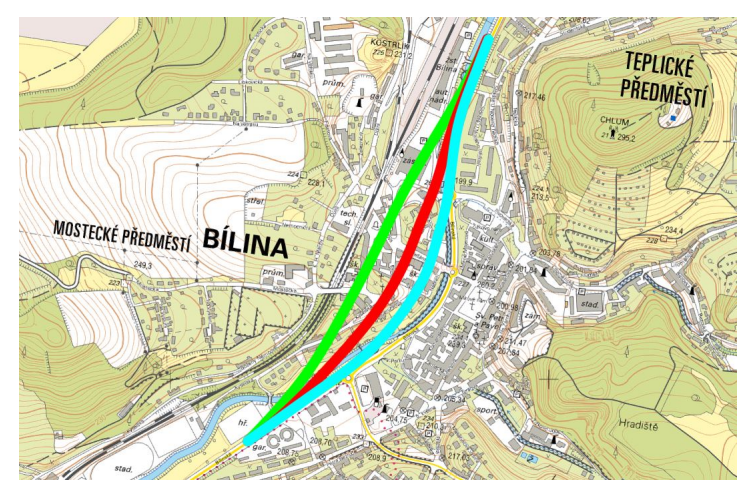

Figure 1. Site plan of the area of interest including Variant $\mathrm{Z}$ tunnel alignment alternatives. 


\section{Geotechnical Investigation}

Prior to initial field work an agreement with the client was made that split the investigation into two phases. The first phase, realised in the second half of 2018, was aimed at both portal sections. The second phase (first half of 2019) investigated geotechnical conditions of the mined part of the tunnel.

The majority of works that were conducted within the investigation are described in the following subchapters. Positioning of all boreholes were determined using a high-precision GNSS receiver. Nine boreholes were realized (maximum depth up to $45 \mathrm{~m}$ ) with total length over $200 \mathrm{~m}$; four of them were cased as groundwater monitoring wells. Soil, rock and groundwater samples for subsequent laboratory tests were extracted from all boreholes, and aquifer and pressure meter tests were conducted in some selected ones.

\subsection{Preparatory WORKS}

Prior to a field work launch it is always necessary to secure entrance permission by the landowner on whose property the boreholes will be located. In the next step it is necessary to prevent potential conflict situations, for example to verify the nonexistence of public utility lines. As the boreholes were located within the city limits a high number of underground utility lines was indeed confirmed; because of this $1 \mathrm{~m}$ deep manually dug trenches were undertaken in almost all borehole localities. The trenches proved a key factor; thanks to them unexpected utility lines were discovered in places where they were not indicated by their respective companies. As a result, some of the boreholes were relocated up to several tens of meters away from their original positions.

A local peculiarity of geotechnical investigation in the city of Bílina is the existence of a mineral water source protection zone. Boring into pre-Tertiary rocks must be approved by the Czech Inspectorate of Spas and Springs (or CISS for short). This permission prescribed certain requirements that needed to be followed during the boring process.

\subsection{CORE DRILling}

In the first phase both portal sections were explored $[3$. Drilling up to the depth of $10 \mathrm{~m}$ was carried out without drilling fluid, using a tungsten carbide drill bit with a single tube core barrel.

The second phase was aimed at the mined part of the tunnel [4. The above-mentioned drilling technology was applied to reach the bedrock. After that, boreholes were cased with a water pressure resistant steel casing (the result of the CISS requirements); the boring continued with a diamond encrusted drill bit and a double tube core barrel up to the final depth.

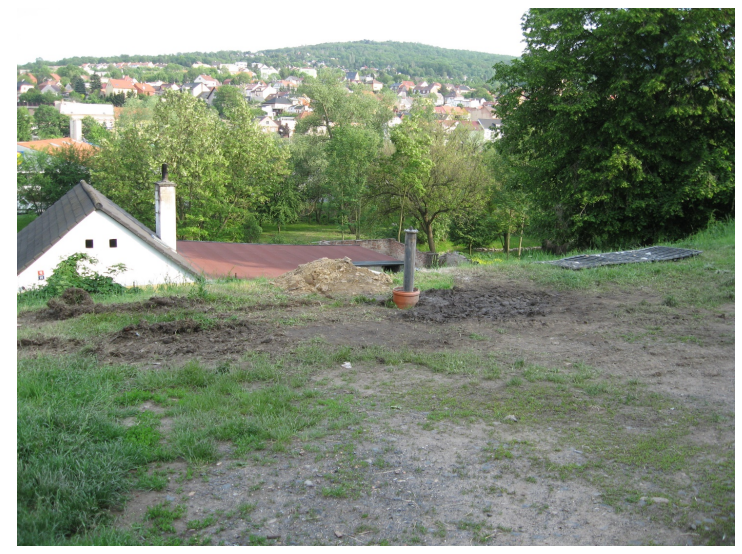

FiguRE 2. Temporary water pressure resistant steel casing of a borehole during realisation (located in an orange KG-System PVC sewage pipe backfilled in the manually dug trench).

\subsection{SAMPLING}

Soil and rock samples, for determination of their physical and mechanical properties by means of laboratory tests, were extracted from all boreholes.

In the course of boring groundwater samples for realtime determination of selected parameters, defined by the CISS, were taken. When the boring finished samples for assessment of any groundwater aggressiveness towards concrete and steel were collected.

\subsection{Field TESTS}

In the cased groundwater monitoring wells aquifer tests (short-term pumping and recovery tests) were performed.

Pressure meter tests were conducted in two boreholes; the tests were performed at three depth levels of each borehole.

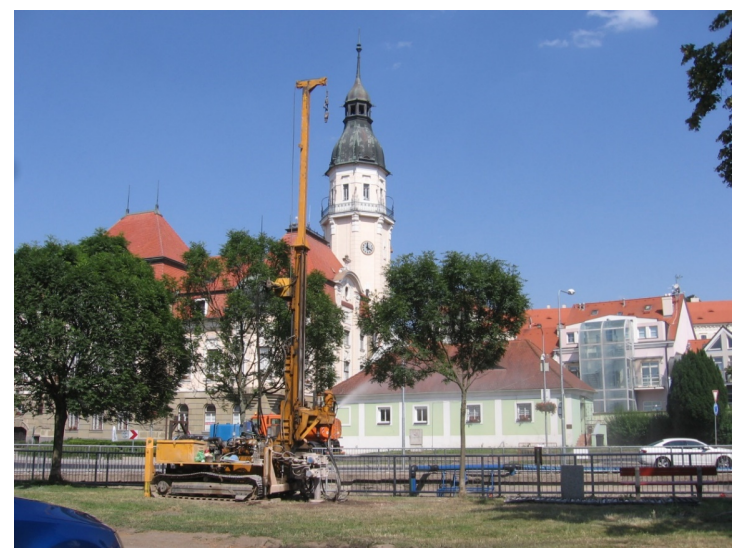

FiguRE 3. Groundwater monitoring well realisation, to the left in the background the historical building of Bílina city hall.

\section{Results of the Geotechnichl INVESTIGATION}

Description of the geological environment of the planned tunnel was based on the work mentioned 
above. For better clarity, the individual tunnel sections are discussed separately.

\subsection{Southern (Most) Portal}

The southern tunnel portal is located in the vicinity of a football field. The geological environment is formed of superficial anthropogenic deposits and underlying fluvial sediments of the Bílina river. The upper clayey part acts as an aquitard that confines the riverbank infiltrated water into the lower sandy layer, thus forming a confined aquifer. In depths under 15 $\mathrm{m}$ orthogneiss bedrock is to be expected.

\subsection{Mined Section of the Tunnel}

The geological environment of the mined part is formed of three types of lower-Paleozoic orthogneiss; these rocks differ in the amount of individual minerals present. The core drilling proved the existence of fault zones that were indicated in the geological map of the area. Boreholes located close to the Bílina river also proved a chemical weathering of orthogneiss in the form of kaolinization.

Classification of individual parts of the tunnel into NATM Excavation Support Classes is not trivial. In the central (deepest) tunnel part, where fresh or slightly weathered rock is expected, Class No. 3 is presumed. In case of highly weathered or tectonically damaged rocks Class No. 4 is necessary. In the portal parts where orthogneiss residual soil is expected Class No. 5a is unavoidable.

\subsection{Northern (Teplice) Portal}

The northern tunnel portal is located near the train station. The geological environment is formed of superficial anthropogenic deposits and underlying Tertiary igneous rocks. Contrary to the results of the desk study very hard basalt layers were recorded; these layers originate from the nearby Chlum hill.

\section{Selected Noteworthy Geotechnical Aspects}

It is necessary to highlight certain aspects that, if neglected, could constitute complications for subsequent investigation and design.

\subsection{Southern (Most) Portal}

In the southern portal area a confined aquifer located in sandy layers of the Bílina river sediments was registered. When the upper clayey layer is penetrated quicksand behavior occurs. During borehole realization wall instability and liquefied sand rising were observed.

\subsection{Mined Section of the Tunnel}

Brittle tectonic rock deformation eases groundwater penetration into the upper parts of the orthogneiss bedrock. After a sufficient amount of time passes the water causes progressive chemical decomposition (kaolinization) of the rock, in worst case up to the residual soil state. Another dangerous factor for the tunnel excavation is the alternation of more and less weathered rock layers; in selected boreholes this was proved even at depths greater than $20 \mathrm{~m}$.

\subsection{Northern (Teplice) Portal}

Laboratory tests proved to the high compressive strength of basalt layers located in the northern portal area. This means complications during construction of the portal, and even rock blasting is not to be excluded. At the same time the extracted rock presents a suitable aggregate source that can be utilised for embankment construction.

\subsection{Geotechnical and Hydrogeological HAZARDS}

The main hazards that complicate the tunnel construction are connected to water and geological environment characteristics. The whole structure is located on the floodplains of the Bílina river and the Syčivka brook.

The structure is placed in the mineral water source protection zone. The mined section of the tunnel passes through the orthogneiss bedrock where the source of the Biliner (or Bílina acidulous water) is also located. All construction works have to be permitted by the CISS.

In the southern portal area quicksand occurs, therefore application of Larssen sheet piling during construction was proposed.

In the mined section of the tunnel tectonic deformation of the bedrock was registered, locally associated to uneven chemical weathering of the orthogneiss. Excavation in this environment can be confronted with tunnel face instability in the form of loosening and falling of individual rock blocks and also overbreak formation.

\section{Conclusion}

The preliminary geotechnical investigation for the Bílina Tunnel described the geological environment of the area. Based on deeper boreholes that reached the bedrock and the field and laboratory tests carried out, the western tunnel alignment alternative was recommended for realisation. Results indicate that with increasing distance from the river the quality of the orthogneiss also increases, or rather the degree of weathering of the tectonically deformed bedrock decreases. For subsequent investigation and design, certain measures were proposed that can facilitate these works, e.g. moving of the tunnel alignment further away from the river or relocation of the portal areas. This is however complicated by other nongeological factors (for example, existence of a railroad and district heating pipes in the area).

Currently only subsequent design work is taking place. For the time being however funding of the project is unclear; it will be addressed at state level. 


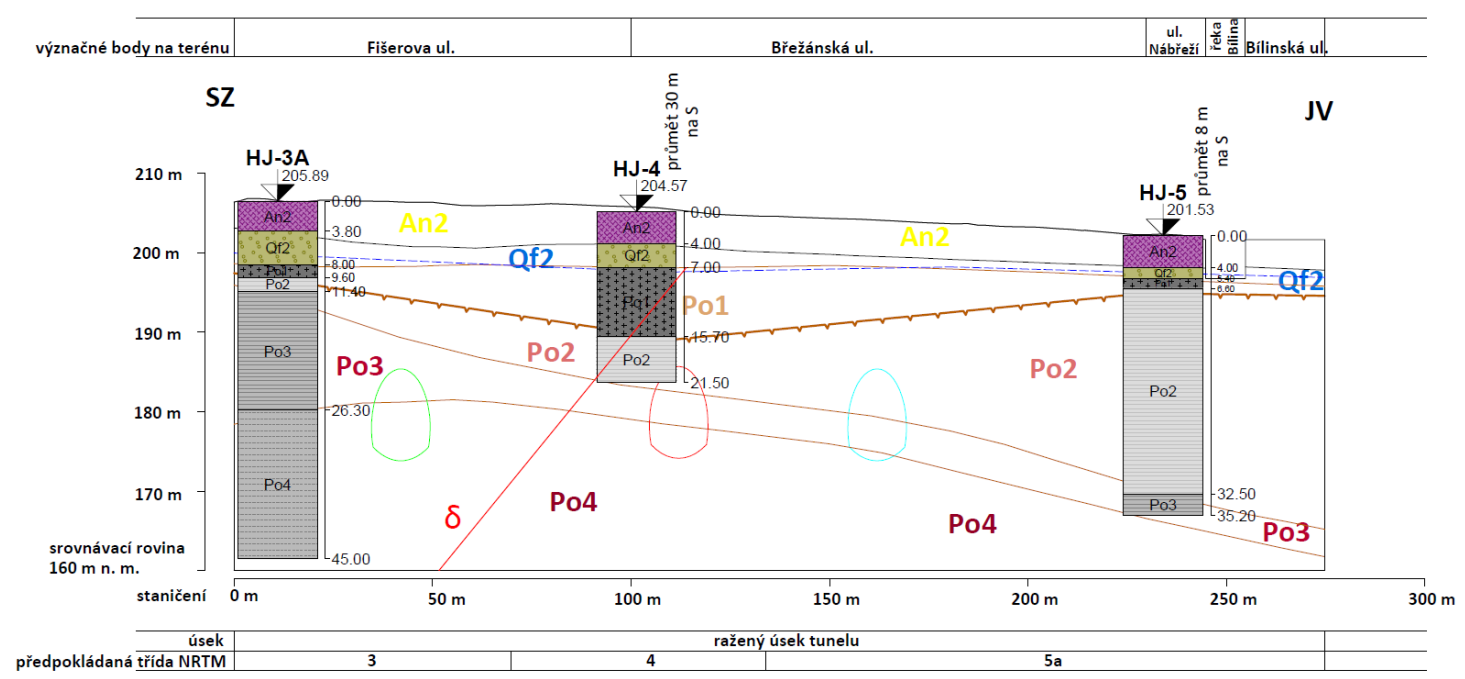

FIGURE 4. Transverse geologic cross-section including individual tunnel alignment alternatives (vertical exaggeration $\mathrm{x} 2)$.

Let us hope that the project will move to completion in the shortest time possible.

\section{REFERENCES}

[1] V. Köllner. Podrobný inženýrskogeologický průzkum Bílina - prütah. 1988. V.O. silnice I/27, I. stavba, Pragoprojekt, Praha.

[2] K. Dusbaba, et al. I/13 Bílina, obchvat - varianta X: technicko-ekonomická studie. 2016. Valbek, spol. s r.o., Ústí nad Labem.
[3] P. Černoch, V. Sotorník. I/13 Bílina, obchvat Realizační dokumentace předběžného geotechnického průzkumu. 2018. INSET s.r.o., Praha.

[4] J. Koštál, V. Sotorník. I/13 Bílina, obchvat - II. etapa předběžného geotechnického prüzkumu. 2019. INSET s.r.o., Praha. 